\title{
Safety and effectiveness of everolimus in maintenance kidney transplant patients in the real-world setting: results from a 2-year post-marketing surveillance study in Japan
}

\author{
Naomi Hayase $^{1} \cdot$ Mariko Yamada $^{2} \cdot$ Shuhei Kaneko $^{3} \cdot$ Yoko Watanabe $^{4}$
}

Received: 8 July 2020 / Accepted: 21 January 2021 / Published online: 11 February 2021

(c) The Author(s) 2021

\begin{abstract}
Background Data on real-world use of everolimus (EVR) in Japanese maintenance kidney transplant (KTx) patients are limited. This post-marketing surveillance study was conducted to assess the safety and effectiveness of EVR, and identify factors affecting renal impairment.

Methods Adult maintenance KTx patients were enrolled within 14 days of initiating EVR. Patient medical data were collected using electronic data capture case report forms at 6 months, 1 , and 2 years after initiating EVR, or at discontinuation. Results All patients receiving EVR in Japan during the surveillance period were enrolled $(N=263)$. Mean time from transplantation to EVR initiation was 75.7 months. Decreased renal function (31.56\%) was the primary reason for initiating EVR. In combination with EVR, the mean daily dose of tacrolimus and cyclosporine could be reduced to $\sim 79$ and $\sim 64 \%$, by 2 years, respectively. Incidences of serious adverse events and adverse drug reactions were 15.97 and $49.43 \%$, respectively. Two-year graft survival rate was $95.82 \%$ and low in patients with baseline estimated glomerular filtration rate (eGFR; modification of diet in renal disease) $<30 \mathrm{~mL} / \mathrm{min} / 1.73 \mathrm{~m}^{2}(69.57 \% ; P<0.0001)$ and urinary protein/creatinine ratio (UPCR) $\geq 0.55 \mathrm{~g} / \mathrm{gCr}$ (84.21\%; $P=0.0206)$. Throughout the survey, mean eGFR values were stable ( $\left.>55 \mathrm{~mL} / \mathrm{min} / 1.73 \mathrm{~m}^{2}\right)$. Renal impairment was influenced by patient and donor age, eGFR, and UPCR at baseline.

Conclusions No new safety concerns for the use of EVR in adult maintenance KTx patients were identified. Early EVR initiation may be considered in these patients before renal function deterioration occurs.
\end{abstract}

Keywords Everolimus · Maintenance kidney transplant patients $\cdot$ Renal impairment · Observational study $\cdot$ Post-marketing surveillance

$\begin{array}{ll}\text { Abbreviations } \\ \text { ABMR } & \text { Antibody-mediated rejection } \\ \text { ADR } & \text { Adverse drug reaction } \\ \mathrm{AE} & \text { Adverse event } \\ \mathrm{C}_{0} & \text { Trough level }\end{array}$

Naomi Hayase

naomi.hayase@novartis.com

1 Novartis Pharma K.K. Medical Division, 23-1, Toranomon 1-chome, Minato-ku, Tokyo 105-6333, Japan

2 Patient Safety Japan Re-Examination Department, Novartis Pharma K.K., Tokyo, Japan

3 Biostatistics Pharma, Integrated Biostatistics Japan, Clinical Development \& Analytics Japan, Novartis Pharma K.K., Tokyo, Japan

4 Immunology, Hepatology \& Dermatology Clinical Development Department, Clinical Development \& Analytics Japan, Novartis Pharma K.K., Tokyo, Japan

$\begin{array}{ll}\text { CNI } & \text { Calcineurin inhibitor } \\ \text { CRF } & \text { Case report form } \\ \text { DSA } & \text { Donor-specific antibodies } \\ \text { eGFR } & \text { Estimated glomerular filtration rate } \\ \text { EVR } & \text { Everolimus } \\ \text { MDRD } & \text { Modification of diet in renal disease } \\ \text { mGFR } & \text { Measured glomerular filtration rate } \\ \text { MMF } & \text { Mycophenolate mofetil } \\ \text { rCsA } & \text { Reduced-exposure cyclosporine } \\ \text { SAE } & \text { Serious adverse event } \\ \text { SD } & \text { Standard deviation } \\ \text { sCsA } & \text { Standard-exposure cyclosporine } \\ \text { UPCR } & \text { Urinary protein/creatinine ratio }\end{array}$




\section{Introduction}

Current immunosuppressive protocols with calcineurin inhibitors (CNIs) provide good short-term efficacy but their long-term use is associated with chronic nephrotoxicity [1, 2], CNI arteriolopathy [3], diabetes [4, 5], and cardiovascular complications [6]. Thus, immunosuppressive strategies that can facilitate CNI minimization/elimination, while maintaining long-term anti-rejection efficacy are being developed [7-9].

Several studies have reported the efficacy and safety of everolimus (EVR) as a maintenance immunosuppressant in kidney transplant (KTx) patients [10-14]. The main reasons for switching to an EVR-based regimen were interstitial fibrosis and tubular atrophy, CNI-associated nephrotoxicity, cancer, viral infections, and generalized vascular disease [10,11].

Although EVR has been approved in Japan for "inhibition of graft rejection in kidney transplantation" in 2011, data on clinical experience with EVR in Japanese maintenance KTx patients are limited. In a previous post-marketing surveillance (PMS) study in Japan, efficacy and safety of EVR in both de novo and maintenance KTx patients was reported up to 2 years. However, no data on renal function, influence of baseline characteristics on efficacy and safety were reported [14]. The current PMS study was planned to assess the safety and effectiveness of EVR in adult maintenance KTx patients and to identify factors responsible for subsequent renal impairment.

\section{Patients and methods}

\section{Survey design and population}

This was a 2-year, observational, non-interventional, multicenter, PMS study conducted between September 2014 and August 2018 by a central registration system. KTx patients aged $\geq 18$ years receiving EVR in the maintenance period were enrolled from December 2014-15. Patients were enrolled within 14 days of initiating EVR and enrollment continued until December 31, 2015. Written informed consent was obtained from all patients before enrollment. Patients who had previously participated in other EVR studies or had exposure to EVR $<3$ months prior to enrollment were excluded. Patient medical data were collected using electronic data capture case report forms (CRFs) at 6 months, 1 and 2 years after initiating EVR, or at discontinuation.

\section{Survey objectives}

The survey objective was to assess the safety and effectiveness of EVR in maintenance KTx patients and to identify baseline (at the time of EVR initiation) characteristics influencing renal impairment by observing changes in renal function before and after EVR use. Safety and effectiveness of EVR and changes in renal function from baseline were also assessed in elderly patients ( $\geq 65$ years).

\section{Sample size determination}

A sample size of 200 patients was determined to explore factors influencing renal impairment after EVR initiation. Using findings from a previous retrospective survey in maintenance KTx patients [11], baseline renal function and donor age were considered as prediction factors, each with two categories (i.e., worse/better baseline renal function and younger/older donors). With 200 patients and a $5 \%$ alpha level using a chi-squared test, the probabilities of detecting a significant difference between the two categories each for baseline renal function and donor age were 78 and $90 \%$, respectively.

\section{Survey endpoints and assessments}

Safety and effectiveness observation periods were defined as 2 years from EVR initiation until discontinuation or graft loss +30 days. Safety endpoints included the assessment of serious adverse events (SAEs), adverse drug reactions (ADRs), death, and ADRs by baseline characteristics. SAEs were defined as life-threatening events or death, permanent or significant disability/impairment, congenital abnormality, in-patient hospitalization or prolongation of hospitalization, or medically significant event. Adverse events (AEs) for which a causal relationship with EVR was likely were treated as ADRs. Terminology for AEs was standardized using the Medical Dictionary for Regulatory Activities/Japanese edition, version 21.0. For all AEs, details of causality, action taken, and outcome at each visit until recovery or stabilization were recorded by the investigator. Effectiveness endpoints included the assessment of graft rejection, graft survival, and patient survival rates by baseline characteristics. Graft rejection was clinically diagnosed with/without biopsy and effectiveness rates were defined as the proportion of patients without rejection. ADRs and treatment effectiveness by baseline characteristics were also assessed in elderly patients.

Renal function after initiating EVR was assessed by change in estimated glomerular filtration rate (eGFR; using the Japanese equation [15], international formula [modification of diet in renal disease; MDRD], and serum cystatin C) over time.

Renal impairment at final assessment was defined as percentage decrease in renal function below the 25 th percentile eGFR (MDRD) value from EVR initiation, and was assessed by baseline characteristics. 
The target trough levels $\left(\mathrm{C}_{0}\right)$ for EVR were determined as $3-8 \mathrm{ng} / \mathrm{mL}$. Mean EVR $\mathrm{C}_{0}$ and the proportion of patients within the $\mathrm{EVR}_{0}$ categories $(<3 \mathrm{ng} / \mathrm{mL}, 3-8 \mathrm{ng} / \mathrm{mL}$, and $>8 \mathrm{ng} / \mathrm{mL}$ ) were assessed at Months 1, 3, 6, 12, and 24, and at discontinuation.

\section{Analysis sets}

The safety and effectiveness analysis sets were defined as patients with at least one fixed CRF volume in whom none of the exclusion criteria (such as deviations in enrollment/ unconfirmed enrollment, patients not receiving EVR, no visit following first dose, unfixed first CRF volume, $<6$ months post-transplantation, off-label use, duplicate cases, outside of the contract period, and participation in clinical study of an unapproved drug) were applied.

\section{Statistical analysis}

To assess the influence of baseline characteristics on ADR or effectiveness, Fisher's exact test (for nominal categorical baseline characteristics) or the Mann-Whitney $U$ test (for ordinal categorical baseline characteristics with more than two levels) were performed, with a two-sided significance level of 5\%. In testing, "unknown," "not reported," and "not evaluable" data were excluded. The Mantel-Haenszel test was performed to adjust the stratified effect of baseline characteristics for which a significant difference $(P<0.05)$ between factors was observed. A factor was suspected to influence ADR or effectiveness if the adjusted analysis showed a significant difference $(P<0.05)$ between factors. Missing values were not imputed and the value from the last assessment point was carried forward for the final assessment. The proportion and odds ratio $(95 \% \mathrm{CI})$ of patients with renal impairment by baseline characteristics were evaluated in a descriptive manner.

\section{Results}

\section{Patient demographics and baseline characteristics}

The survey enrolled 263 patients from 34 medical institutions, and CRFs for all patients were fixed on August 31, 2018. All 263 patients were included in the safety and effectiveness analysis sets. Demographic and baseline characteristics are presented in Table 1. Mean patient and donor ages were $51.5 \pm 13.10$ years and $55.8 \pm 11.69$ years, respectively. Of the 263 patients, 56 (21.29\%) were elderly ( $\geq 65$ years). The mean time from transplantation to EVR initiation was $75.7 \pm 63.17$ months. Decreased renal function $(31.56 \%)$ was the primary reason for initiating EVR. Baseline eGFR (Japanese equation) was $\leq 60 \mathrm{~mL} / \mathrm{min} / 1.73 \mathrm{~m}^{2}$ in $\sim 80 \%$ of patients. EVR was discontinued in 65 (24.71\%) patients; AEs being the primary reason for discontinuation in 46 $(17.49 \%)$ patients.

\section{Immunosuppression}

The mean treatment and observation periods were 613.2 and 644.3 days, respectively. Most patients (72.62\%) received EVR for at least 2 years with a mean daily dose of $1.3 \mathrm{mg}$. Mean EVR $\mathrm{C}_{0}$ was within the target range throughout the observation period and was $4.39 \pm 2.23 \mathrm{ng} / \mathrm{mL}$ at the final assessment (Fig. 1a). Adherence to the target EVR $\mathrm{C}_{0}$ was seen in $58.02 \%$ of patients (Fig. 1b). During the safety observation period, $182(69.20 \%)$ patients received concomitant tacrolimus and $82(31.18 \%)$ patients received concomitant cyclosporine at least once. By 2 years, the mean daily dose of tacrolimus and cyclosporine was reduced to $\sim 79$ and $\sim 64 \%$ of the dose, respectively. The majority of the patients also received mycophenolate mofetil (MMF) $(n=224$ [85.17\%]) and corticosteroids $(n=225[85.55 \%])$ during the survey.

\section{Safety}

The overall incidence of SAEs was $15.97 \%$. Kidney transplant rejection and renal impairment were the most common (1.14\% each) SAEs. ADRs occurred in $49.43 \%$ of patients, most commonly reported were stomatitis $(15.97 \%)$, proteinuria $(9.89 \%)$, hyperlipidemia $(5.32 \%)$, and peripheral edema (3.80\%) (Table 2).

Two deaths were reported during the survey. One patient (76 years) died from gastric cancer. Onset was seen on Day 28 post-EVR initiation, and the time from transplantation to EVR initiation was 4.2 years. Another patient ( 72 years) died from subarachnoid hemorrhage with an onset of 40 days after EVR initiation. The time post-transplantation to EVR initiation was 6.2 years. Both deaths were reported to be unrelated to EVR treatment.

While investigating the incidence of ADRs by baseline characteristics (Table 3), history of antibody-mediated rejection (ABMR), donor type, and reasons for initiating EVR were identified as contributing factors. The frequency of ADRs was higher in patients with versus without a history of ABMR (77.27 versus 47.08\%; $P=0.0074)$. Most ADRs occurred in patients receiving an allograft from brain-death donors $(63.64 \%)$, followed by living $(51.11 \%)$ and cardiac arrest $(28.0 \%)$ donors $(P=0.0494)$. However, adjusted analysis for ABMR and donor type categories showed no significant differences, suggesting that these findings may be due to confounders. The incidence of ADRs $(P=0.0010)$ by reasons for initiating EVR is provided in Table 3. As the adjusted analysis also found significant differences, reasons for initiating EVR should be considered as an influencing factor. The incidence of ADRs in 
Table 1 Demographic and baseline characteristics (safety analysis set; $N=263$ )

\begin{tabular}{|c|c|c|c|}
\hline Characteristics & Number of patients, $n(\%)$ & Characteristics & $\begin{array}{l}\text { Number of } \\
\text { patients, } n(\%)\end{array}$ \\
\hline Sex & & HLA mismatches & \\
\hline Male & $163(61.98)$ & $<3$ & $79(30.04)$ \\
\hline Female & $100(38.02)$ & $\geq 3$ & $132(50.19)$ \\
\hline Age (years), mean \pm SD & $51.5 \pm 13.10$ & Unknown & $52(19.77)$ \\
\hline$<50$ & $125(47.53)$ & Immunological risk at $\mathrm{Tx}$ & \\
\hline$\geq 50$ and $<65$ & $82(31.18)$ & High risk: ABO-i or PRA(+) & $61(23.19)$ \\
\hline$\geq 65$ & $56(21.29)$ & Normal risk & $196(74.52)$ \\
\hline Donor age (years), mean \pm SD & $55.8 \pm 11.69$ & Unknown & $6(2.28)$ \\
\hline$<50$ & $65(24.71)$ & Donor type & \\
\hline$\geq 50$ and $<65$ & $118(44.87)$ & Living & $225(85.55)$ \\
\hline$\geq 65$ & $55(20.91)$ & Cardiac arrest & $25(9.51)$ \\
\hline Unknown & $25(9.51)$ & Brain death & $11(4.18)$ \\
\hline Time since Tx (months), mean \pm SD & $75.7 \pm 63.17$ & Unknown & $2(0.76)$ \\
\hline$\geq 6$ months and $<1$ year & $48(18.25)$ & Reason for initiating EVR & \\
\hline$\geq 1$ year and $<5$ years & $73(27.76)$ & Decreased renal function & $83(31.56)$ \\
\hline$\geq 5$ years and $<10$ years & $88(33.46)$ & Malignant tumor & $36(13.69)$ \\
\hline$\geq 10$ years & $54(20.53)$ & Cardiovascular event & $4(1.52)$ \\
\hline Body weight $(\mathrm{kg})$, mean $\pm \mathrm{SD}$ & $58.8 \pm 11.69(n=240)$ & Arteriosclerosis & $29(11.03)$ \\
\hline Height $(\mathrm{cm})$, mean \pm SD & $163.7 \pm 8.85(n=243)$ & Cytomegalovirus infection & $11(4.18)$ \\
\hline $\mathrm{BMI}\left(\mathrm{kg} / \mathrm{m}^{2}\right)$, mean $\pm \mathrm{SD}$ & $21.9 \pm 3.63(n=234)$ & Antimetabolite-related AE & $3(1.14)$ \\
\hline$<18.5$ & $39(14.83)$ & MMF-related AE & $11(4.18)$ \\
\hline$\geq 18.5$ and $<25.0$ & $160(60.84)$ & Other & $86(32.70)$ \\
\hline$\geq 25.0$ & $35(13.31)$ & eGFR (Japanese equation; $\left.\mathrm{mL} / \mathrm{min} / 1.73 \mathrm{~m}^{2}\right)^{\mathrm{c}}$ & \\
\hline Unknown & $29(11.03)$ & $<30$ & $51(19.39)$ \\
\hline Primary disease leading to $\mathrm{KT}^{\mathrm{a}}{ }^{\mathrm{a}}$ & & $\geq 30$ and $\leq 60$ & $161(61.22)$ \\
\hline Chronic glomerulonephritis & $80(30.42)$ & $>60$ & $48(18.25)$ \\
\hline Focal glomerulosclerosis & $10(3.80)$ & Unknown & $3(1.14)$ \\
\hline IgA nephropathy & $51(19.39)$ & eGFR (MDRD; $\left.\mathrm{mL} / \mathrm{min} / 1.73 \mathrm{~m}^{2}\right)^{\mathrm{c}}$ & \\
\hline Interstitial nephritis & $2(0.76)$ & $<30$ & $23(8.75)$ \\
\hline Polycystic kidney & $20(7.60)$ & $\geq 30$ and $\leq 60$ & $121(46.01)$ \\
\hline Nephrosclerosis & $14(5.32)$ & $>60$ & $116(44.11)$ \\
\hline Hypoplastic/dysplastic kidney & $4(1.52)$ & Unknown & $3(1.14)$ \\
\hline Diabetic nephropathy & $26(9.89)$ & eGFR (serum cystatin $\left.\mathrm{C} ; \mathrm{mL} / \mathrm{min} / 1.73 \mathrm{~m}^{2}\right)^{\mathrm{c}}$ & \\
\hline Other & $60(22.81)$ & $<30$ & $22(8.37)$ \\
\hline History of graft rejection ${ }^{b}$ & & $\geq 30$ and $\leq 60$ & $80(30.42)$ \\
\hline Cellular rejection & $12(4.56)$ & $>60$ & $26(9.89)$ \\
\hline ABMR & $22(8.37)$ & Unknown & $135(51.33)$ \\
\hline Relationship with donor & & $\operatorname{UPCR}(\mathrm{g} / \mathrm{gCr})^{\mathrm{c}}$ & \\
\hline Blood relative & $129(49.05)$ & $<0.55$ & 147 (55.89) \\
\hline Spouse & 89 (33.84) & $\geq 0.55$ & $19(7.22)$ \\
\hline Other & 45 (17.11) & Unknown & 97 (36.88) \\
\hline Unknown & $0(0.0)$ & & \\
\hline
\end{tabular}

As the safety and effectiveness analysis sets are the same, the composition ratios remain the same for both sets

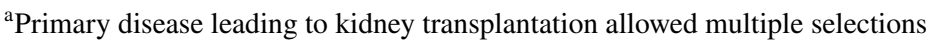

${ }^{\mathrm{b}}$ Within 6 months before the start of EVR treatment

${ }^{c}$ At the start of EVR treatment

$A B M R$ antibody-mediated rejection, $A B O-i$ ABO incompatible, $A E$ adverse event, $B M I$ body mass index, $e G F R$ estimated glomerular filtration rate, $E V R$ everolimus, $H L A$ human leukocyte antigen, $I g A$ immunoglobulin A, KTx kidney transplantation, $M D R D$ modification of diet in renal disease, $M M F$ mycophenolate mofetil, $P R A$ panel reactive antibody, $S D$ standard deviation, $T x$ transplantation, $U P C R$ urinary protein/creatinine ratio 
Fig. 1 Exposure of everolimus (safety analysis set): a Mean (SD) EVR $\mathrm{C}_{0}$ over time, b Proportion of patients with adherence to the EVR target range (3-8 ng/mL). The shaded box indicates the protocol-defined EVR target $\mathrm{C}_{0}$ range (3-8 ng/ $\mathrm{mL})$. *Final assessment means at the end of EVR treatment or at discontinuation. $C_{0}$ trough level, $E V R$ everolimus, $M$ month, $S D$ standard deviation
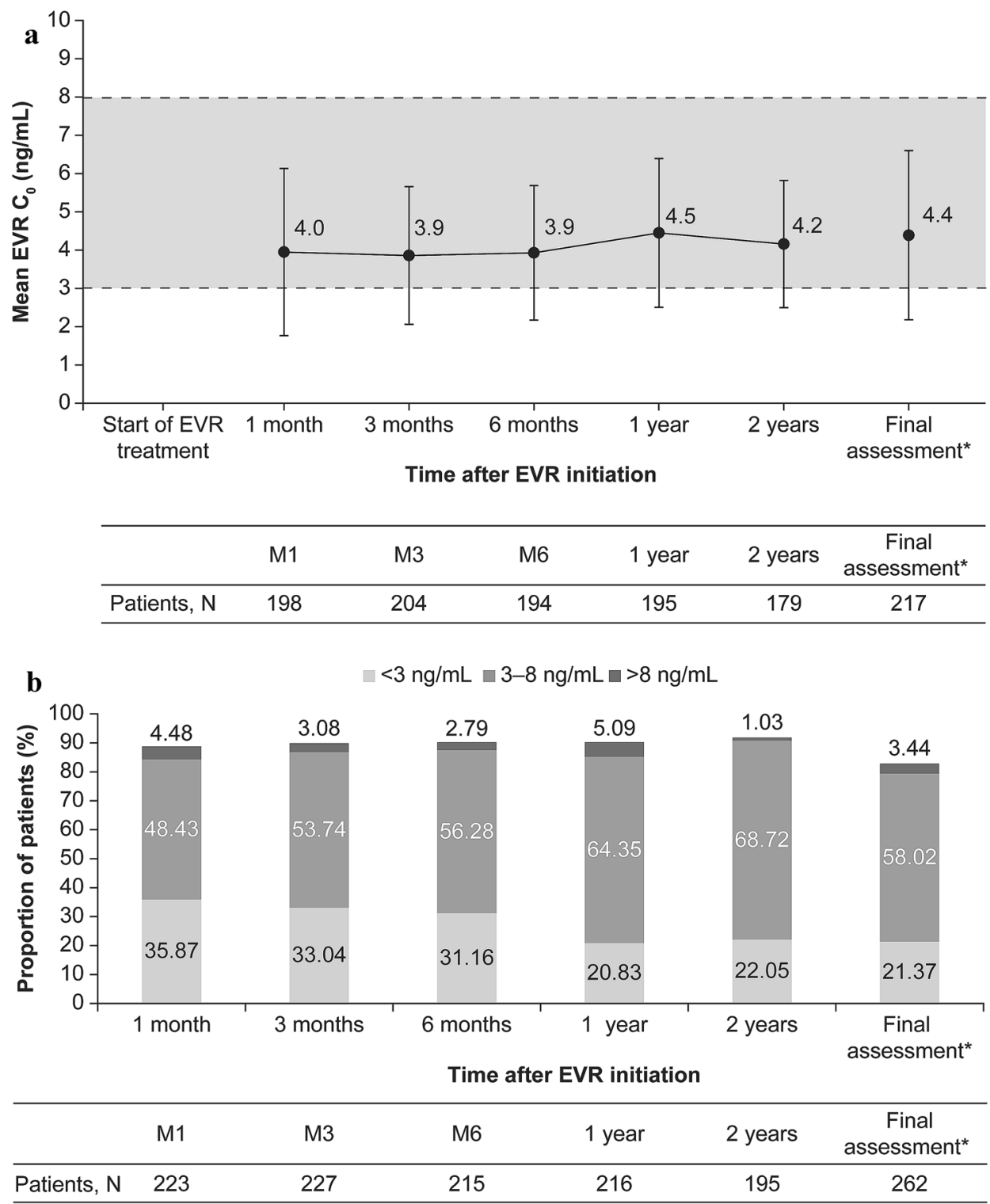

elderly patients $(41.07 \%)$ was numerically lower than in non-elderly patients $(51.69 \%)$.

\section{Effectiveness}

Overall incidence of graft rejection was low (6.84\%) in this population. In total, 19 events were reported in 18 patients (Table S1). The 2-year graft survival rate was $95.82 \%$ and the patient survival rate was $99.24 \%$. Effectiveness analysis by baseline characteristics is presented in Table 4 .

\section{Graft rejection}

Baseline characteristics such as nephrosclerosis, history of cellular rejection and ABMR, and eGFR (Japanese equation) were found to influence graft rejection (Table 4). Patients with nephrosclerosis before transplantation showed a lower rate of effectiveness $(71.43 \%)$ compared to patients without nephrosclerosis $(94.38 \% ; P=0.0101)$. The rates of effectiveness were lower in patients with versus without a history of cellular rejection (66.67 versus $94.80 \% ; P=0.0044)$ and in patients with versus without a history of ABMR (77.27 versus $95.00 \% ; P=0.0083)$. As the adjusted analysis also found a significant difference, the influence of nephrosclerosis and history of both cellular rejection and ABMR could not be eliminated. The rates of effectiveness were higher in patients within the eGFR categories (Japanese equation) of $\geq 30$ and $\leq 60 \mathrm{~mL} / \mathrm{min} / 1.73 \mathrm{~m}^{2}$, and $>60 \mathrm{~mL} / \mathrm{min} / 1.73 \mathrm{~m}^{2}$ $(P=0.0220)$. These differences by eGFR category may be due to confounding factors, as the adjusted analysis showed no significant differences. Effectiveness rates were 
Table 2 Incidence rates $(\geq 1 \%)$ of ADRs by preferred term (safety analysis set; $N=263$ )

\begin{tabular}{ll}
\hline Incidence of ADRs $n / N(\%)$ & $130 / 263(49.43)$ \\
Type of ADR & Incidence, $n(\%)$ \\
\hline Nasopharyngitis & $3(1.14)$ \\
Kidney transplant rejection & $3(1.14)$ \\
Dyslipidemia & $6(2.28)$ \\
Lipid metabolism disorder & $3(1.14)$ \\
Hyperlipidemia & $14(5.32)$ \\
Diarrhea & $3(1.14)$ \\
Stomatitis & $42(15.97)$ \\
Rash & $4(1.52)$ \\
Proteinuria & $26(9.89)$ \\
Renal impairment & $5(1.90)$ \\
Concomitant disease aggravated & $3(1.14)$ \\
Peripheral edema & $10(3.80)$ \\
Albumin urine present & $7(2.66)$ \\
Blood creatinine increased & $3(1.14)$ \\
Protein urine & $3(1.14)$ \\
Protein urine present & $5(1.90)$ \\
\hline
\end{tabular}

$A D R$ adverse drug reaction

comparable between elderly and non-elderly patients $(96.43$ versus $92.27 \% ; P=0.3786)$.

\section{Graft survival}

Graft survival rates were influenced by baseline eGFR (Japanese equation and MDRD) and urinary protein/creatinine ratio (UPCR). Patients with lower baseline eGFR showed lower graft survival rates compared to patients with higher eGFR ( $>60 \mathrm{~mL} / \mathrm{min} / 1.73 \mathrm{~m}^{2} ; P=0.0003$ for eGFR [Japanese equation] and $P<0.0001$ for eGFR [MDRD]). Baseline UPCR of $<0.55 \mathrm{~g} / \mathrm{gCr}$ showed a higher 2-year graft survival rate $(97.96 \%)$ versus $\mathrm{UPCR} \geq 0.55 \mathrm{~g} / \mathrm{gCr}(84.21 \%$; $P=0.0206$ ) (Table 4). As adjusted analysis failed to show significant differences, the influence of baseline eGFR (Japanese equation) and UPCR could be due to confounding factors. Graft survival rates were comparable between elderly and non-elderly patients ( 96.43 versus $95.65 \% ; P=1.0000)$.

\section{Patient survival}

Patient survival rates were associated with baseline characteristics such as patient and donor age. The survival rates were lower in elderly $(96.43 \%)$ versus non-elderly (100.00\%; $P=0.0447$ ) patients (Table 4). Adjusted analysis for patient age also showed significant differences. The two deaths reported during the survey due to gastric cancer and subarachnoid hemorrhage, respectively, were seen in elderly patients. However, the causal relationship between these AEs leading to death and EVR was eliminated for each instance; therefore, an advanced age was not considered to directly affect survival in these patients. Patient survival rates by donor age categories $(P=0.0406)$ are provided in Table 4 . The adjusted analysis showed that the influence of donor age on patient survival could be due to confounding factors.

\section{Renal function}

Baseline mean eGFR values were maintained until 2 years after the treatment or the final assessment (Fig. 2). For patients aged $<65$ years and $\geq 65$ years, mean eGFR (MDRD) at baseline and final assessment were comparable (Fig. 3a). Among patients with baseline UPCR $\geq 0.55 \mathrm{~g} / \mathrm{gCr}$, mean eGFR (MDRD) at the final assessment was numerically lower compared to baseline (Fig. 3b).

The proportion of patients with renal impairment (eGFR [MDRD]) at the final assessment by baseline characteristics is presented in Table 5 (renal impairment assessments by eGFR [Japanese equation] and eGFR [serum cystatin C] are given in Table S2 and S3, respectively). Baseline factors such as patient and donor age, eGFR, and UPCR were found to influence renal impairment after EVR treatment. Incidence of renal impairment was lower in the patient age group of $\geq 65$ years $(16.98 \%)$ versus $<50$ years $(31.71 \%)$. In patients with donors aged $\geq 65$ years, the incidence of renal impairment was higher $(38.89 \%)$ versus donors aged $<50$ years $(20.31 \%)$. Irrespective of the formula used for measuring eGFR, more patients with baseline $\mathrm{eGFR}<30 \mathrm{~mL} / \mathrm{min} / 1.73 \mathrm{~m}^{2}$ showed renal impairment at the final assessment. Of 23 patients with baseline eGFR $\left(\right.$ MDRD) $<30 \mathrm{~mL} / \mathrm{min} / 1.73 \mathrm{~m}^{2}, 12(52.17 \%)$ showed renal impairment at the final assessment. Similarly, incidence $(52.63 \%)$ of renal impairment was higher in patients with baseline UPCR $\geq 0.55 \mathrm{~g} / \mathrm{gCr}$.

\section{Discussion}

This large PMS study in Japan reported real-world use of EVR in 263 adults, maintenance KTx patients (with 225 living donor transplants), and identified baseline characteristics influencing the subsequent renal impairment. AEs were the primary reason for EVR discontinuation and the most common ADRs reported were stomatitis, proteinuria, hyperlipidemia, and peripheral edema. These safety findings are consistent with those previously reported in the literature for EVR [9-12]. In our survey, with EVR initiation, the mean daily dose of tacrolimus and cyclosporine was reduced to $\sim 79$ and $\sim 64 \%$ by 2 years, respectively. Even though blood CNI concentrations were measured at various time points, mean $\mathrm{CNI} \mathrm{C}_{0}$ levels were not reported due to a lack of data 
Table 3 Incidence of ADRs by baseline characteristics (safety analysis set)

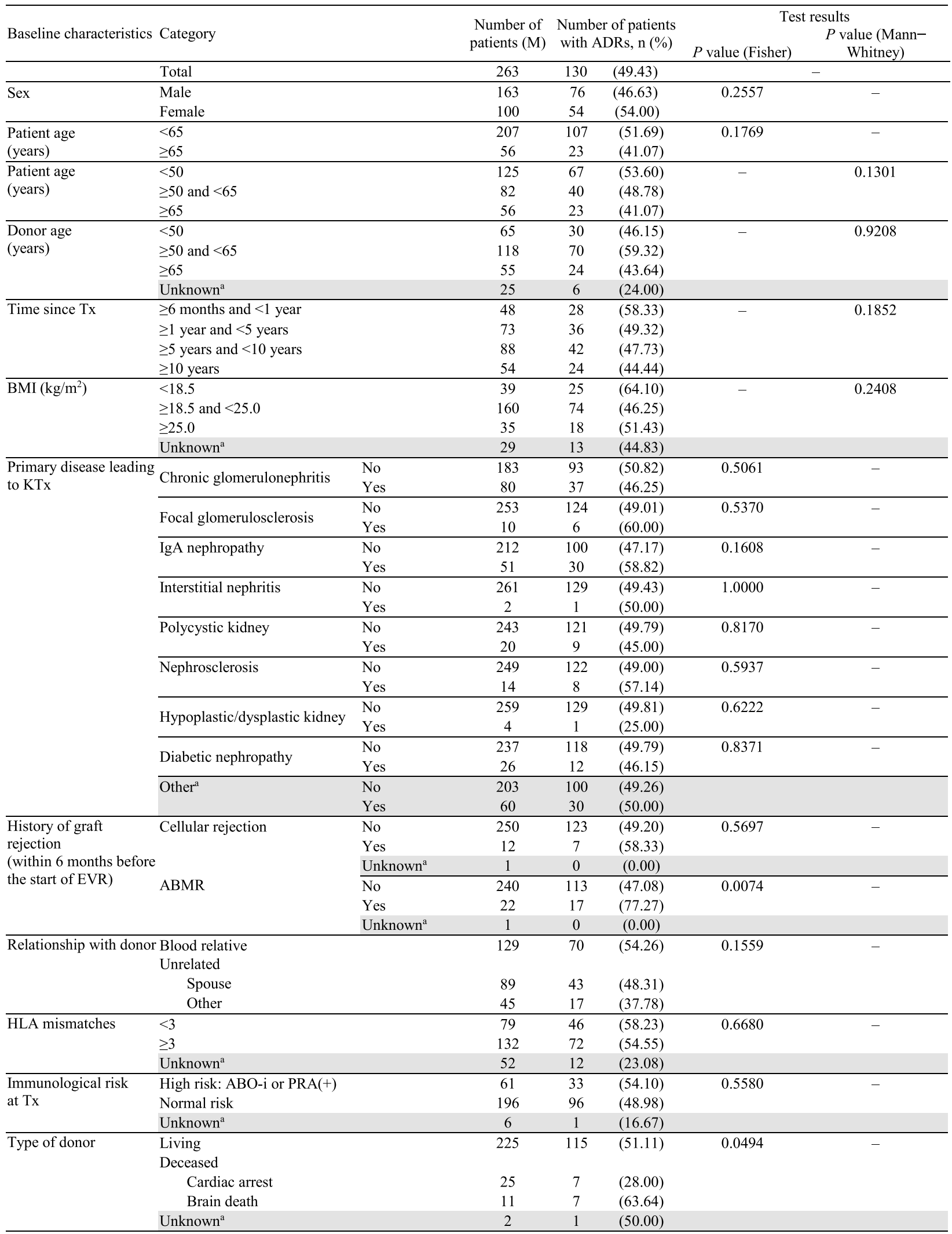


Table 3 (continued)

\begin{tabular}{|c|c|c|c|c|c|c|}
\hline \multirow{2}{*}{ Baseline characteristics } & \multirow[b]{2}{*}{ Category } & \multirow{2}{*}{$\begin{array}{l}\text { Number of } \\
\text { patients (M) }\end{array}$} & \multirow{2}{*}{\multicolumn{2}{|c|}{$\begin{array}{l}\text { Number of patients } \\
\text { with ADRs, n (\%) }\end{array}$}} & \multicolumn{2}{|c|}{ Test results } \\
\hline & & & & & & $P$ value (Mann- \\
\hline \multirow{8}{*}{$\begin{array}{l}\text { Reasons for } \\
\text { initiating EVR }\end{array}$} & Decreased renal function & 83 & 49 & $(59.04)$ & 0.0010 & - \\
\hline & Malignant tumor & 36 & 14 & $(38.89)$ & & \\
\hline & Cardiovascular event & 4 & 2 & $(50.00)$ & & \\
\hline & Arteriosclerosis & 29 & 4 & (13.79) & & \\
\hline & Cytomegalovirus infection & 11 & 5 & $(45.45)$ & & \\
\hline & Antimetabolite-related $\mathrm{AE}$ & 3 & 2 & $(66.67)$ & & \\
\hline & MMF-related AE & 11 & 6 & $(54.55)$ & & \\
\hline & Other & 86 & 48 & $(55.81)$ & & \\
\hline \multirow{4}{*}{$\begin{array}{l}\text { eGFR (Japanese } \\
\text { equation; } \\
\left.\mathrm{mL} / \mathrm{min} / 1.73 \mathrm{~m}^{2}\right)^{\mathrm{b}}\end{array}$} & $<30$ & 51 & 27 & $(52.94)$ & - & 0.7713 \\
\hline & $\geq 30$ and $\leq 60$ & 161 & 75 & $(46.58)$ & & \\
\hline & $>60$ & 48 & 27 & $(56.25)$ & & \\
\hline & Unknown $^{\mathrm{a}}$ & 3 & 1 & $(33.33)$ & & \\
\hline \multirow{4}{*}{$\begin{array}{l}\text { eGFR (MDRD; } \\
\left.\mathrm{mL} / \mathrm{min} / 1.73 \mathrm{~m}^{2}\right)^{\mathrm{b}}\end{array}$} & $<30$ & 23 & 13 & $(56.52)$ & - & 0.1570 \\
\hline & $\geq 30$ and $\leq 60$ & 121 & 64 & $(52.89)$ & & \\
\hline & $>60$ & 116 & 52 & $(44.83)$ & & \\
\hline & Unknown $^{\mathrm{a}}$ & 3 & 1 & $(33.33)$ & & \\
\hline \multirow{4}{*}{$\begin{array}{l}\text { eGFR (serum cystatin } \\
\left.\mathrm{C} ; \mathrm{mL} / \mathrm{min} / 1.73 \mathrm{~m}^{2}\right)^{\mathrm{b}}\end{array}$} & $<30$ & 22 & 12 & $(54.55)$ & - & 0.1694 \\
\hline & $\geq 30$ and $\leq 60$ & 80 & 35 & $(43.75)$ & & \\
\hline & $>60$ & 26 & 9 & $(34.62)$ & & \\
\hline & Unknown $^{\mathrm{a}}$ & 135 & 74 & $(54.81)$ & & \\
\hline \multirow[t]{3}{*}{$\overline{\mathrm{UPCR}}(\mathrm{g} / \mathrm{gCr})^{\mathrm{b}}$} & $<0.55$ & 147 & 68 & $(46.26)$ & 0.0885 & - \\
\hline & $\geq 0.55$ & 19 & 13 & $(68.42)$ & & \\
\hline & Unknown $^{\mathrm{a}}$ & 97 & 49 & $(50.52)$ & & \\
\hline
\end{tabular}

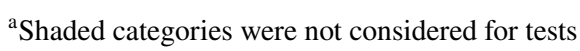

${ }^{\mathrm{b}}$ At the start of EVR treatment

$A B M R$ antibody-mediated rejection, $A B O-i \mathrm{ABO}$ incompatible, $A D R$ adverse drug reaction, $A E$ adverse event, $B M I$ body mass index, $e G F R$ estimated glomerular filtration rate, $E V R$ everolimus, $H L A$ human leukocyte antigen, $I g A$ immunoglobulin A, $K T x$ kidney transplantation, $M D R D$ modification of diet in renal disease, $M M F$ mycophenolate mofetil, $P R A$ panel reactive antibody, $T x$ transplantation, UPCR urinary protein/creatinine ratio

on the timing of blood sampling. However, post-hoc analysis (data not shown) showed an overall decline in blood CNI levels over the course of EVR treatment.

Late conversion ( $\geq 3$ years after transplantation) to EVR has shown to impact renal function and graft survival [11]. Although the overall graft survival rate $(95.82 \%)$ at 2 years was high in our survey, low rates were seen in patients with baseline eGFR (MDRD) $<30 \mathrm{~mL} / \mathrm{min} / 1.73 \mathrm{~m}^{2}$ and $\mathrm{UPCR} \geq 0.55 \mathrm{~g} / \mathrm{gCr}$. Similar results were observed in the ASCERTAIN study (assessing the effect of late-conversion [mean 5.6 years post-transplant] to EVR with CNI elimination/minimization in maintenance KTx patients with renal impairment at baseline [defined as GFR $30-70 \mathrm{~mL} / \mathrm{min}$ ]), where overall, $93.3 \%$ of patients receiving EVR survived with a functioning graft at Month (M) 24 [12]. This suggests that longer follow-up (beyond 2 years) is needed to conclude the clinical benefits of EVR.

In the ASCERTAIN study, renal function was stable in all treatment groups at M24. Although no overall renal benefit was seen with EVR-based regimen, post-hoc analyses showed that the increase in measured glomerular filtration rate (mGFR) was higher in patients with baseline creatinine clearance $(\mathrm{CrCl})>50 \mathrm{~mL} / \mathrm{min}$ in the $\mathrm{CNI}$ elimination group versus the control group $(P=0.017)$ [12]. In a retrospective study in KTx patients, improvement in renal function was statistically significant at 1 -year in patients who were converted (median 5.8 years post-transplant) to EVR with baseline $\mathrm{CrCl} \geq 40 \mathrm{~mL} / \mathrm{min}$ and proteinuria $<550 \mathrm{mg} /$ day $(P=0.005)$ [11]. Consistent with these findings, baseline mean eGFR values were maintained during our survey. However, renal impairment at final assessment was higher in patients with baseline eGFR (MDRD) $<30 \mathrm{~mL} / \mathrm{min} / 1.73 \mathrm{~m}^{2}$ and UPCR $\geq 0.55 \mathrm{~g} / \mathrm{gCr}$. This suggests that patients with good baseline renal function may benefit from an EVRbased regimen. In contrast, Nojima et al. reported significant improvement in renal function at 1-year in Japanese KTx patients, including patients with low baseline eGFR $(<30 \mathrm{~mL} / \mathrm{min})$ converted to EVR-based regimen at a mean 7.4 years post-transplant. This could be due to the low CNI $\mathrm{C}_{0}$ levels observed in this study [16].

The lower incidence of renal impairment in elderly patients versus patients aged $<50$ years could be due to a high proportion of (i) elderly patients who received a graft from donors aged $<65$ years and (ii) patients aged $<50$ years who received a graft from donors aged $\geq 50$ years. As renal function declines with age [11], graft function may have 
Table 4 Effectiveness analysis by baseline characteristics (effectiveness analysis set)

\begin{tabular}{|c|c|c|c|c|c|c|c|c|c|c|c|c|}
\hline \multirow{3}{*}{$\begin{array}{l}\text { Baseline } \\
\text { characteristics }\end{array}$} & \multirow{2}{*}{\multicolumn{2}{|c|}{ Category }} & \multirow[b]{2}{*}{$\begin{array}{l}\text { Number of } \\
\text { patients, M }\end{array}$} & \multicolumn{3}{|c|}{ No graft rejection } & \multicolumn{3}{|c|}{$\begin{array}{l}\text { Graft survival of transplanted } \\
\text { kidney }\end{array}$} & \multicolumn{3}{|c|}{ Patient survival } \\
\hline & & & & & $\begin{array}{l}\text { oortion of } \\
\text { atients } \\
\text { ceiving } \\
\text { ffective } \\
\text { atment, } \\
\mathrm{n}(\%)\end{array}$ & $P$ value & & $\begin{array}{l}\text { portion of } \\
\text { atients } \\
\text { ceiving } \\
\text { ffective } \\
\text { atment, } \\
\mathrm{n}(\%)\end{array}$ & $P$ value & & $\begin{array}{l}\text { oortion of } \\
\text { atients } \\
\text { ceiving } \\
\text { fective } \\
\text { atment, } \\
\text { n (\%) }\end{array}$ & $P$ value \\
\hline & Total & & 263 & 245 & $(93.16)$ & & 252 & $(95.82)$ & & 261 & (99.24) & \\
\hline \multirow[t]{2}{*}{$\overline{\text { Sex }}$} & Male & & 163 & 152 & $(93.25)$ & 1.0000 & 154 & (94.48) & 0.2147 & 162 & (99.39) & 1.0000 \\
\hline & Female & & 100 & 93 & $(93.00)$ & & 98 & $(98.00)$ & & 99 & $(99.00)$ & \\
\hline \multirow{2}{*}{$\begin{array}{l}\text { Patient age } \\
\text { (years) }\end{array}$} & $<65$ & & 207 & 191 & $(92.27)$ & 0.3786 & 198 & $(95.65)$ & 1.0000 & 207 & $(100.00)$ & 0.0447 \\
\hline & $\geq 65$ & & 56 & 54 & $(96.43)$ & & 54 & $(96.43)$ & & 54 & $(96.43)$ & \\
\hline \multirow{3}{*}{$\begin{array}{l}\text { Patient age } \\
\text { (years) }\end{array}$} & $<50$ & & 125 & 115 & $(92.00)$ & $0.3381^{\mathrm{a}}$ & 119 & $(95.20)$ & $0.6515^{\mathrm{a}}$ & 125 & $(100.00)$ & $0.0369^{\mathrm{a}}$ \\
\hline & $\geq 50$ and $<65$ & & 82 & 76 & $(92.68)$ & & 79 & $(96.34)$ & & 82 & $(100.00)$ & \\
\hline & $\geq 65$ & & 56 & 54 & $(96.43)$ & & 54 & $(96.43)$ & & 54 & $(96.43)$ & \\
\hline \multirow{4}{*}{$\begin{array}{l}\begin{array}{l}\text { Donor age } \\
\text { (years) }\end{array} \\
\text { (a) }\end{array}$} & $<50$ & & 65 & 60 & $(92.31)$ & $0.9177^{\mathrm{a}}$ & 62 & $(95.38)$ & $0.5335^{\mathrm{a}}$ & 65 & $(100.00)$ & $0.0406^{\mathrm{a}}$ \\
\hline & $\geq 50$ and $<65$ & & 118 & 110 & $(93.22)$ & & 116 & $(98.31)$ & & 118 & $(100.00)$ & \\
\hline & $\geq 65$ & & 55 & 51 & $(92.73)$ & & 51 & $(92.73)$ & & 53 & $(96.36)$ & \\
\hline & Unknown $^{\mathrm{b}}$ & & 25 & 24 & $(96.00)$ & & 23 & $(92.00)$ & & 25 & $(100.00)$ & \\
\hline \multirow[t]{4}{*}{ Time since $\mathrm{Tx}$} & $\geq 6$ months and $<1$ year & & 48 & 41 & $(85.42)$ & $0.0940^{\mathrm{a}}$ & 47 & $(97.92)$ & $0.0765^{\mathrm{a}}$ & 48 & $(100.00)$ & $0.8997^{\mathrm{a}}$ \\
\hline & $\geq 1$ year and $<5$ years & & 73 & 68 & $(93.15)$ & & 71 & $(97.26)$ & & 72 & $(98.63)$ & \\
\hline & $\geq 5$ years and $<10$ years & & 88 & 86 & $(97.73)$ & & 85 & $(96.59)$ & & 87 & $(98.86)$ & \\
\hline & $\geq 10$ years & & 54 & 50 & $(92.59)$ & & 49 & $(90.74)$ & & 54 & $(100.00)$ & \\
\hline \multirow[t]{4}{*}{$\overline{\mathrm{BMI}}\left(\mathrm{kg} / \mathrm{m}^{2}\right)$} & $<18.5$ & & 39 & 39 & $(100.00)$ & $0.1391^{\mathrm{a}}$ & 38 & $(97.44)$ & $0.9244^{\mathrm{a}}$ & 39 & $(100.00)$ & $0.9784^{\mathrm{a}}$ \\
\hline & $\geq 18.5$ and $<25.0$ & & 160 & 146 & $(91.25)$ & & 153 & $(95.63)$ & & 159 & $(99.38)$ & \\
\hline & $\geq 25.0$ & & 35 & 32 & (91.43) & & 34 & $(97.14)$ & & 35 & $(100.00)$ & \\
\hline & Unknown $^{\mathrm{b}}$ & & 29 & 28 & $(96.55)$ & & 27 & $(93.10)$ & & 28 & $(96.55)$ & \\
\hline \multirow{18}{*}{$\begin{array}{l}\text { Primary disease } \\
\text { leading to KTx }\end{array}$} & Chronic & No & 183 & 172 & $(93.99)$ & 0.4327 & 173 & $(94.54)$ & 0.1811 & 181 & $(98.91)$ & 1.0000 \\
\hline & glomerulonephritis & Yes & 80 & 73 & $(91.25)$ & & 79 & $(98.75)$ & & 80 & $(100.00)$ & \\
\hline & Focal glomerulosclerosis & No & 253 & 235 & $(92.89)$ & 1.0000 & 242 & $(95.65)$ & 1.0000 & 251 & $(99.21)$ & 1.0000 \\
\hline & & Yes & 10 & 10 & $(100.00)$ & & 10 & $(100.00)$ & & 10 & $(100.00)$ & \\
\hline & IgA nephropathy & No & 212 & 197 & $(92.92)$ & 1.0000 & 205 & $(96.70)$ & 0.2321 & 210 & $(99.06)$ & 1.0000 \\
\hline & & Yes & 51 & 48 & $(94.12)$ & & 47 & $(92.16)$ & & 51 & $(100.00)$ & \\
\hline & Interstitial nephritis & No & 261 & 243 & $(93.10)$ & 1.0000 & 250 & $(95.79)$ & 1.0000 & 259 & (99.23) & 1.0000 \\
\hline & & Yes & 2 & 2 & $(100.00)$ & & 2 & $(100.00)$ & & 2 & $(100.00)$ & \\
\hline & Polycystic kidney & No & 243 & 225 & $(92.59)$ & 0.3756 & 234 & $(96.30)$ & 0.1998 & 242 & (99.59) & 0.1466 \\
\hline & & Yes & 20 & 20 & $(100.00)$ & & 18 & $(90.00)$ & & 19 & $(95.00)$ & \\
\hline & Nephrosclerosis & No & 249 & 235 & $(94.38)$ & 0.0101 & 238 & $(95.58)$ & 1.0000 & 247 & $(99.20)$ & 1.0000 \\
\hline & & Yes & 14 & 10 & $(71.43)$ & & 14 & $(100.00)$ & & 14 & $(100.00)$ & \\
\hline & Hypoplastic/dysplastic & No & 259 & 241 & $(93.05)$ & 1.0000 & 248 & $(95.75)$ & 1.0000 & 257 & $(99.23)$ & 1.0000 \\
\hline & & Yes & 4 & 4 & $(100.00)$ & & 4 & $(100.00)$ & & 4 & $(100.00)$ & \\
\hline & Diabetic nephropathy & No & 237 & 220 & $(92.83)$ & 1.0000 & 226 & $(95.36)$ & 0.6084 & 236 & $(99.58)$ & 0.1883 \\
\hline & & Yes & 26 & 25 & $(96.15)$ & & 26 & $(100.00)$ & & 25 & $(96.15)$ & \\
\hline & Other $^{b}$ & No & 203 & 190 & $(93.60)$ & & 196 & $(96.55)$ & & 201 & $(99.01)$ & \\
\hline & & Yes & 60 & 55 & $(91.67)$ & & 56 & (93.33) & & 60 & $(100.00)$ & \\
\hline \multirow{6}{*}{$\begin{array}{l}\text { History of graft } \\
\text { rejection } \\
\text { (within } 6 \text { months } \\
\text { before the start of } \\
\text { EVR treatment) }\end{array}$} & Cellular rejection & No & 250 & 237 & $(94.80)$ & 0.0044 & 240 & $(96.00)$ & 0.4091 & 248 & $(99.20)$ & 1.0000 \\
\hline & & Yes & 12 & 8 & $(66.67)$ & & 11 & $(91.67)$ & & 12 & $(100.00)$ & \\
\hline & & Unknown $^{\mathrm{b}}$ & 1 & 0 & $(0.00)$ & & 1 & $(100.00)$ & & 1 & $(100.00)$ & \\
\hline & & No & 240 & 228 & $(95.00)$ & 0.0083 & 229 & $(95.42)$ & 0.6069 & 238 & $(99.17)$ & 1.0000 \\
\hline & ABMR & Yes & 22 & 17 & $(77.27)$ & & 22 & $(100.00)$ & & 22 & $(100.00)$ & \\
\hline & & Unknown $^{\mathrm{b}}$ & 1 & 0 & $(0.00)$ & & 1 & $(100.00)$ & & 1 & (100.00) & \\
\hline
\end{tabular}

been impaired at transplantation in patients $<50$ years who received a graft from elderly donors. However, adjusted analysis with confounders was not performed to confirm this finding.
The low graft rejection rate in our survey could be because most patients received EVR + CNI + MMF + corticosteroids therapy. Despite the significant difference in the effectiveness rates between patients with versus without nephrosclerosis, clinical factors potentially associated 
Table 4 (continued)

\begin{tabular}{|c|c|c|c|c|c|c|c|c|c|c|c|}
\hline & & & \multicolumn{3}{|c|}{ No graft rejection } & \multicolumn{3}{|c|}{$\begin{array}{c}\text { Graft survival of transplanted } \\
\text { kidney }\end{array}$} & \multicolumn{3}{|c|}{ Patient survival } \\
\hline $\begin{array}{l}\begin{array}{l}\text { Baseline } \\
\text { characteristics }\end{array} \\
\text { nate }\end{array}$ & Category & $\begin{array}{l}\text { Number of } \\
\text { patients, } M\end{array}$ & \multicolumn{2}{|c|}{$\begin{array}{l}\text { Proportion of } \\
\text { patients } \\
\text { receiving } \\
\text { effective } \\
\text { treatment, } \\
\text { n }(\%)\end{array}$} & $P$ value & \multicolumn{2}{|c|}{$\begin{array}{l}\text { Proportion of } \\
\text { patients } \\
\text { receiving } \\
\text { effective } \\
\text { treatment, } \\
\mathrm{n}(\%)\end{array}$} & $P$ value & \multicolumn{2}{|c|}{$\begin{array}{l}\text { Proportion of } \\
\text { patients } \\
\text { receiving } \\
\text { effective } \\
\text { treatment, } \\
\mathrm{n}(\%)\end{array}$} & $P$ value \\
\hline \multirow{4}{*}{$\begin{array}{l}\text { Relationship with } \\
\text { donor }\end{array}$} & Blood relative & 129 & 121 & $(93.80)$ & 0.7616 & 122 & $(94.57)$ & 0.1326 & 129 & $(100.00)$ & 0.1424 \\
\hline & Unrelated & & & & & & & & & & \\
\hline & Spouse & 89 & 83 & $(93.26)$ & & 88 & $(98.88)$ & & 87 & $(97.75)$ & \\
\hline & Other & 45 & 41 & $(91.11)$ & & 42 & $(93.33)$ & & 45 & $(100.00)$ & \\
\hline \multirow[t]{3}{*}{ HLA mismatches } & $<3$ & 79 & 74 & $(93.67)$ & 0.7893 & 74 & $(93.67)$ & 0.1537 & 78 & $(98.73)$ & 1.0000 \\
\hline & $\geq 3$ & 132 & 121 & $(91.67)$ & & 129 & $(97.73)$ & & 131 & $(99.24)$ & \\
\hline & Unknown $^{\mathrm{b}}$ & 52 & 50 & $(96.15)$ & & 49 & $(94.23)$ & & 52 & $(100.00)$ & \\
\hline \multirow{3}{*}{$\begin{array}{l}\text { Immunological risk at } \\
\text { Tx }\end{array}$} & High risk: $\mathrm{ABO}-\mathrm{i}$ or $\mathrm{PRA}(+)$ & 61 & 56 & $(91.80)$ & 0.5433 & 60 & $(98.36)$ & 0.4598 & 60 & $(98.36)$ & 0.4191 \\
\hline & Normal risk & 196 & 185 & $(94.39)$ & & 187 & $(95.41)$ & & 195 & $(99.49)$ & \\
\hline & Unknown & 6 & 4 & $(66.67)$ & & 5 & $(83.33)$ & & 6 & $(100.00)$ & \\
\hline \multirow[t]{5}{*}{ Type of donor } & Living & 225 & 211 & $(93.78)$ & 0.5886 & 216 & $(96.00)$ & 0.5698 & 223 & $(99.11)$ & 1.0000 \\
\hline & Deceased & & & & & & & & & & \\
\hline & Cardiac arrest & 25 & 23 & $(92.00)$ & & 23 & $(92.00)$ & & 25 & $(100.00)$ & \\
\hline & Brain death & 11 & 10 & $(90.91)$ & & 11 & $(100.00)$ & & 11 & $(100.00)$ & \\
\hline & Unknown $^{\mathrm{b}}$ & 2 & 1 & $(50.00)$ & & 2 & $(100.00)$ & & 2 & $(100.00)$ & \\
\hline \multirow{8}{*}{$\begin{array}{l}\text { Reasons for initiating } \\
\text { EVR }\end{array}$} & Decreased renal function & 83 & 77 & $(92.77)$ & 0.2180 & 77 & $(92.77)$ & 0.6421 & 83 & $(100.00)$ & 0.1309 \\
\hline & Malignant tumor related & 36 & 36 & $(100.00)$ & & 35 & $(97.22)$ & & 34 & $(94.44)$ & \\
\hline & Cardiovascular event & 4 & 3 & $(75.00)$ & & 4 & $(100.00)$ & & 4 & $(100.00)$ & \\
\hline & Arteriosclerosis & 29 & 27 & $(93.10)$ & & 28 & $(96.55)$ & & 29 & $(100.00)$ & \\
\hline & Cytomegalovirus infection & 11 & 9 & $(81.82)$ & & 10 & $(90.91)$ & & 11 & $(100.00)$ & \\
\hline & Antimetabolite-related $\mathrm{AE}$ & 3 & 3 & $(100.00)$ & & 3 & $(100.00)$ & & 3 & $(100.00)$ & \\
\hline & MMF-related AE & 11 & 11 & $(100.00)$ & & 11 & $(100.00)$ & & 11 & $(100.00)$ & \\
\hline & Other & 86 & 79 & $(91.86)$ & & 84 & $(97.67)$ & & 86 & $(100.00)$ & \\
\hline \multirow{4}{*}{$\begin{array}{l}\text { eGFR (Japanese } \\
\text { equation; } \\
\left.\mathrm{mL} / \mathrm{min} / 1.73 \mathrm{~m}^{2}\right)^{\mathrm{c}}\end{array}$} & $<30$ & 51 & 44 & $(86.27)$ & $0.0220^{\mathrm{a}}$ & 44 & $(86.27)$ & $0.0003^{\mathrm{a}}$ & 51 & $(100.00)$ & $0.9877^{\mathrm{a}}$ \\
\hline & $\geq 30$ and $\leq 60$ & 161 & 151 & $(93.79)$ & & 158 & $(98.14)$ & & 160 & $(99.38)$ & \\
\hline & $>60$ & 48 & 47 & $(97.92)$ & & 48 & $(100.00)$ & & 48 & $(100.00)$ & \\
\hline & Unknown $^{\mathrm{b}}$ & 3 & 3 & $(100.00)$ & & 2 & $(66.67)$ & & 2 & $(66.67)$ & \\
\hline \multirow{4}{*}{$\begin{array}{l}\text { eGFR (MDRD; } \\
\left.\mathrm{mL} / \mathrm{min} / 1.73 \mathrm{~m}^{2}\right)^{\mathrm{c}}\end{array}$} & $<30$ & 23 & 21 & $(91.30)$ & $0.1613^{\mathrm{a}}$ & 16 & $(69.57)$ & $<0.0001^{\mathrm{a}}$ & 23 & $(100.00)$ & $0.4958^{\mathrm{a}}$ \\
\hline & $\geq 30$ and $\leq 60$ & 121 & 110 & $(90.91)$ & & 118 & $(97.52)$ & & 120 & $(99.17)$ & \\
\hline & $>60$ & 116 & 111 & $(95.69)$ & & 116 & $(100.00)$ & & 116 & $(100.00)$ & \\
\hline & Unknown $^{\mathrm{b}}$ & 3 & 3 & $(100.00)$ & & 2 & $(66.67)$ & & 2 & $(66.67)$ & \\
\hline \multirow{4}{*}{$\begin{array}{l}\text { eGFR (serum cystatin } \\
\left.\mathrm{C} ; \mathrm{mL} / \mathrm{min} / 1.73 \mathrm{~m}^{2}\right)^{\mathrm{c}}\end{array}$} & $<30$ & 22 & 20 & $(90.91)$ & $0.1376^{\mathrm{a}}$ & 20 & $(90.91)$ & $0.0818^{\mathrm{a}}$ & 21 & $(95.45)$ & $0.0991^{\mathrm{a}}$ \\
\hline & $\geq 30$ and $\leq 60$ & 80 & 76 & $(95.00)$ & & 78 & $(97.50)$ & & 80 & $(100.00)$ & \\
\hline & $>60$ & 26 & 26 & $(100.00)$ & & 26 & $(100.00)$ & & 26 & $(100.00)$ & \\
\hline & Unknown $^{\mathrm{b}}$ & 135 & 123 & $(91.11)$ & & 128 & $(94.81)$ & & 134 & $(99.26)$ & \\
\hline \multirow[t]{3}{*}{ UPCR $(\mathrm{g} / \mathrm{gCr})^{\mathrm{c}}$} & $<0.55$ & 147 & 138 & $(93.88)$ & 0.1435 & 144 & (97.96) & 0.0206 & 147 & $(100.00)$ & - \\
\hline & $\geq 0.55$ & 19 & 16 & $(84.21)$ & & 16 & $(84.21)$ & & 19 & $(100.00)$ & \\
\hline & Unknown $^{\mathrm{b}}$ & 97 & 91 & $(93.81)$ & & 92 & $(94.85)$ & & 95 & (97.94) & \\
\hline
\end{tabular}

${ }^{a} P$ values calculated using the Mann - Whitney $U$ test. All other $P$ values are calculated using Fisher's exact test

${ }^{\mathrm{b}}$ Shaded categories were not considered for tests

${ }^{\mathrm{c}}$ At the start of EVR treatment

$A B M R$ antibody-mediated rejection, $A B O-i \mathrm{ABO}$ incompatible, $A E$ adverse event, $B M I$ body mass index, $e G F R$ estimated glomerular filtration rate, $E V R$ everolimus, $H L A$ human leukocyte antigen, $I g A$ immunoglobulin A, KTx kidney transplantation, $M D R D$ modification of diet in renal disease, $M M F$ mycophenolate mofetil, $P R A$ panel reactive antibody, $T x$ transplantation, UPCR urinary protein/creatinine ratio

with the observed difference could not be identified in this survey setting due to a small number of patients with 
Fig. 2 Mean (SD) change in eGFR over time (safety analysis set). *Final assessment means at the end of EVR treatment or at discontinuation. $e G F R$ estimated glomerular filtration rate, $E V R$ everolimus, $M$ month, $M D R D$ modification of diet in renal disease, $S D$ standard deviation

Fig. 3 Mean (SD) change in eGFR (MDRD; safety analysis set): a By patient age ( $<65$ years vs $\geq 65$ years), b By UPCR categories $(<0.55 \mathrm{~g} /$ $\mathrm{gCr} v \mathrm{vs} \geq 0.55 \mathrm{~g} / \mathrm{gCr}$ ). *Final assessment means at the end of EVR treatment or at discontinuation; ${ }^{\dagger}$ Changes over time in the renal function data during the observation period were calculated for patients who had data at each measurement time point out of the 263 patients in the safety analysis set. $e G F R$ estimated glomerular filtration rate, $E V R$ everolimus, $M D R D$ modification of diet in renal disease, $S D$ standard deviation, UPCR urinary protein/creatinine ratio

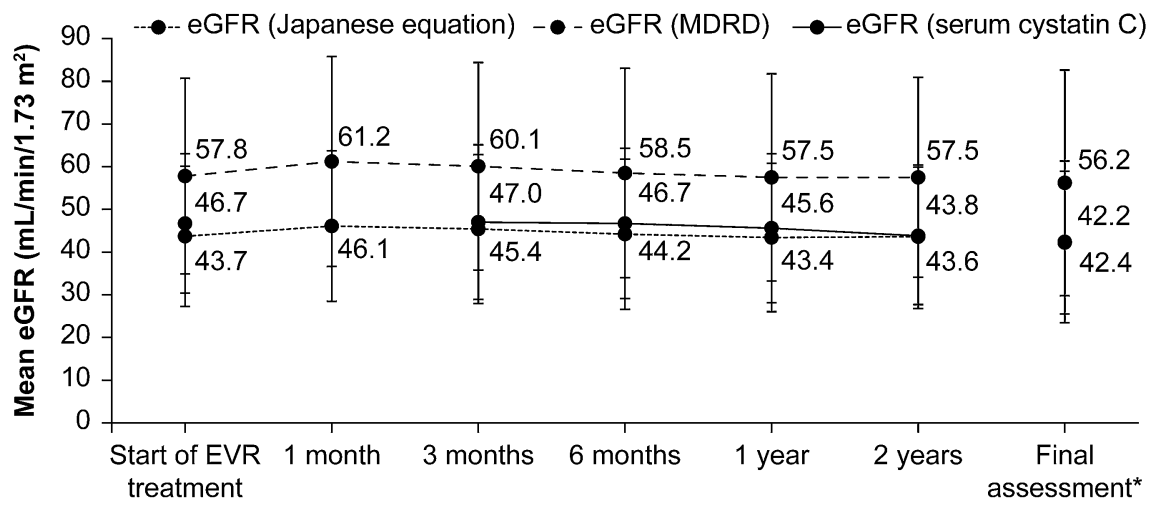

Time after EVR initiation

\begin{tabular}{lccccccc}
\hline Patients, N & $\begin{array}{c}\text { Start of EVR } \\
\text { treatment }\end{array}$ & M1 & M3 & M6 & 1 year & 2 years & $\begin{array}{c}\text { Final } \\
\text { assessment }^{*}\end{array}$ \\
\hline Japanese & 260 & 222 & 227 & 215 & 216 & 194 & 261 \\
equation & 260 & 222 & 227 & 215 & 216 & 194 & 261 \\
MDRD & 128 & 0 & 109 & 110 & 91 & 84 & 102 \\
Serum cystatin C & & & &
\end{tabular}

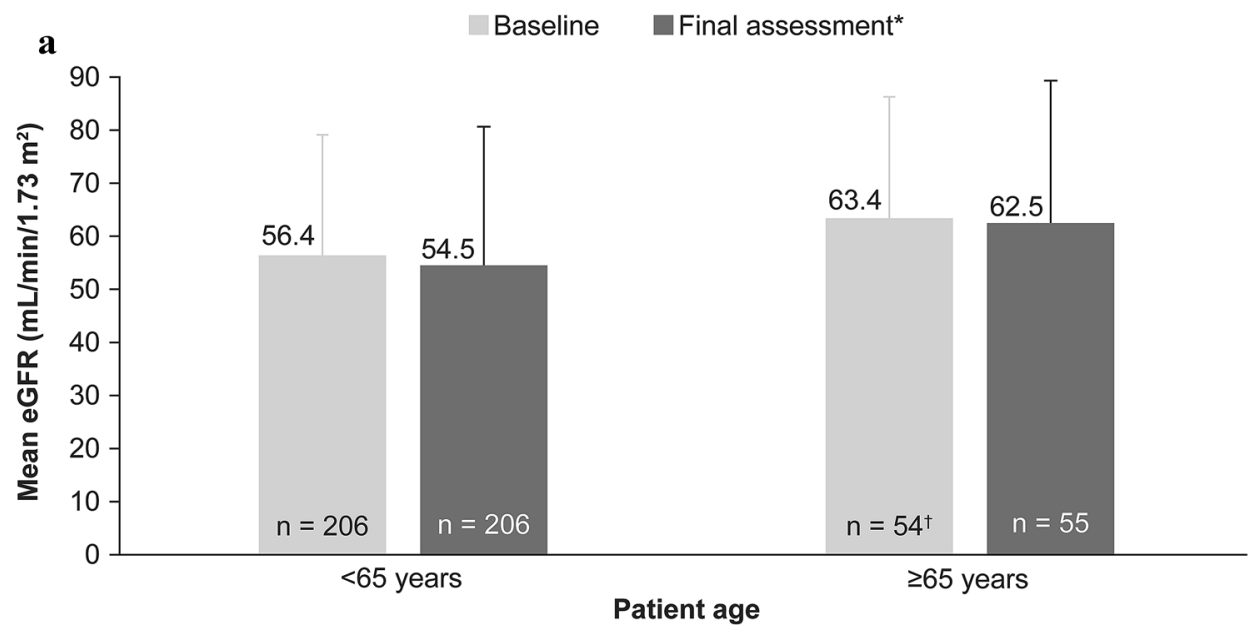

b

Baseline

Final assessment ${ }^{*}$

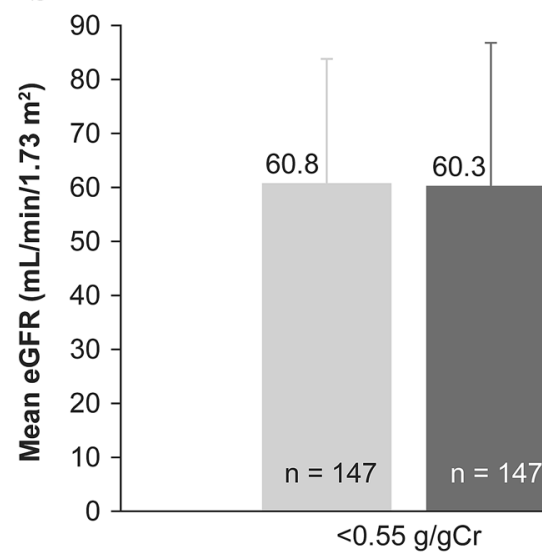

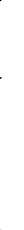


Table 5 Proportion of patients with renal impairment by baseline characteristics: percentage decrease in renal function below the 25 th percentile eGFR (MDRD)

\begin{tabular}{|c|c|c|c|c|c|c|}
\hline \multirow[t]{2}{*}{$\begin{array}{l}\text { Baseline } \\
\text { characteristics }\end{array}$} & \multirow[t]{2}{*}{$\begin{array}{l}\text { Category } \\
\text { Total }\end{array}$} & \multicolumn{2}{|c|}{$\begin{array}{l}\text { Number of } \\
\text { patients }(\%)\end{array}$} & \multicolumn{2}{|c|}{$\begin{array}{c}\text { Proportion of } \\
\text { patients with } \\
\text { renal impairment } \\
(\%)\end{array}$} & \multirow[t]{2}{*}{ OR $(95 \% \mathrm{CI})$} \\
\hline & & & 58 & 64 & $(24.81)$ & \\
\hline \multirow{2}{*}{$\begin{array}{l}\text { Patient age } \\
\text { (years) }\end{array}$} & $<65$ & 205 & $(79.46)$ & 55 & $(26.83)$ & Reference \\
\hline & $\geq 65$ & 53 & $(20.54)$ & 9 & $(16.98)$ & $0.558(0.256-1.218)$ \\
\hline \multirow{3}{*}{$\begin{array}{l}\text { Patient age } \\
\text { (years) }\end{array}$} & $<50$ & 123 & $(47.67)$ & 39 & $(31.71)$ & Reference \\
\hline & $\geq 50$ and $<65$ & 82 & $(31.78)$ & 16 & $(19.51)$ & $0.522(0.268-1.016)$ \\
\hline & $\geq 65$ & 53 & $(20.54)$ & 9 & $(16.98)$ & $0.441(0.196-0.992)$ \\
\hline \multirow{4}{*}{$\begin{array}{l}\text { Donor age } \\
\text { (years) }\end{array}$} & $<50$ & 64 & $(24.81)$ & 13 & $(20.31)$ & Reference \\
\hline & $\geq 50$ and $<65$ & 116 & $(44.96)$ & 24 & $(20.69)$ & $1.023(0.480-2.181)$ \\
\hline & $\geq 65$ & 54 & $(20.93)$ & 21 & $(38.89)$ & $2.497(1.101-5.661)$ \\
\hline & Unknown $^{\mathrm{a}}$ & 24 & $(9.30)$ & 6 & $(25.00)$ & \\
\hline \multirow[t]{4}{*}{ Time since $\mathrm{Tx}$} & $\geq 6$ months and $<1$ year & 48 & $(18.60)$ & 11 & $(22.92)$ & Reference \\
\hline & $\geq 1$ year and $<5$ years & 72 & $(27.91)$ & 20 & $(27.78)$ & $1.294(0.554-3.021)$ \\
\hline & $\geq 5$ years and $<10$ years & 85 & $(32.95)$ & 18 & $(21.18)$ & $0.904(0.386-2.116)$ \\
\hline & $\geq 10$ years & 53 & $(20.54)$ & 15 & $(28.30)$ & $1.328(0.540-3.266)$ \\
\hline \multirow{3}{*}{ HLA mismatches } & $<3$ & 77 & $(29.84)$ & 19 & $(24.68)$ & Reference \\
\hline & $\geq 3$ & 130 & $(50.39)$ & 29 & $(22.31)$ & $0.876(0.452-1.700)$ \\
\hline & Unknown $^{\mathrm{a}}$ & 51 & (19.77) & 16 & $(31.37)$ & \\
\hline \multirow{3}{*}{ Immunological risk at $\mathrm{Tx}$} & High risk & 61 & $(23.64)$ & 11 & $(18.03)$ & Reference \\
\hline & Normal risk & 192 & $(74.42)$ & 50 & $(26.04)$ & $1.600(0.773-3.313)$ \\
\hline & Unknown $^{\mathrm{a}}$ & 5 & $(1.94)$ & 3 & $(60.00)$ & \\
\hline \multirow{8}{*}{ Reasons for initiating EVR } & Decreased renal function & 80 & $(31.01)$ & 22 & $(27.50)$ & Reference \\
\hline & Malignant tumor & 35 & $(13.57)$ & 5 & $(14.29)$ & $0.439(0.151-1.276)$ \\
\hline & Cardiovascular event & 4 & $(1.55)$ & 2 & $(50.00)$ & $2.636(0.350-19.883)$ \\
\hline & Arteriosclerosis & 29 & $(11.24)$ & 7 & $(24.14)$ & $0.839(0.314-2.239)$ \\
\hline & Cytomegalovirus infection & 11 & $(4.26)$ & 4 & $(36.36)$ & $1.506(0.401-5.656)$ \\
\hline & Antimetabolite-related AE & 3 & $(1.16)$ & 0 & $(0.00)$ & -- \\
\hline & MMF-related AE & 11 & $(4.26)$ & 3 & $(27.27)$ & $0.989(0.240-4.069)$ \\
\hline & Other & 85 & $(32.95)$ & 21 & $(24.71)$ & $0.865(0.431-1.734)$ \\
\hline \multirow{3}{*}{$\begin{array}{l}\text { eGFR (Japanese equation; } \\
\left.\mathrm{mL} / \mathrm{min} / 1.73 \mathrm{~m}^{2}\right)^{\mathrm{b}}\end{array}$} & $<30$ & 50 & $(19.38)$ & 19 & $(38.00)$ & Reference \\
\hline & $\geq 30$ and $\leq 60$ & 160 & $(62.02)$ & 37 & $(23.13)$ & $0.491(0.249-0.968)$ \\
\hline & $>60$ & 48 & $(18.60)$ & 8 & $(16.67)$ & $0.326(0.126-0.844)$ \\
\hline \multirow{3}{*}{$\begin{array}{l}\text { eGFR (MDRD; } \\
\left.\mathrm{mL} / \mathrm{min} / 1.73 \mathrm{~m}^{2}\right)^{\mathrm{b}}\end{array}$} & $<30$ & 23 & $(8.91)$ & 12 & $(52.17)$ & Reference \\
\hline & $\geq 30$ and $\leq 60$ & 119 & $(46.12)$ & 36 & $(30.25)$ & $0.398(0.161-0.985)$ \\
\hline & $>60$ & 116 & $(44.96)$ & 16 & $(13.79)$ & $0.147(0.055-0.388)$ \\
\hline \multirow{4}{*}{$\begin{array}{l}\text { eGFR (serum cystatin } \mathrm{C} \text {; } \\
\left.\mathrm{mL} / \mathrm{min} / 1.73 \mathrm{~m}^{2}\right)^{\mathrm{b}}\end{array}$} & $<30$ & 22 & $(8.53)$ & 10 & $(45.45)$ & Reference \\
\hline & $\geq 30$ and $\leq 60$ & 79 & $(30.62)$ & 18 & $(22.78)$ & $0.354(0.132-0.953)$ \\
\hline & $>60$ & 26 & $(10.08)$ & 3 & (11.54) & $0.157(0.036-0.679)$ \\
\hline & Unknown $^{\mathrm{a}}$ & 131 & $(50.78)$ & 33 & $(25.19)$ & \\
\hline \multirow[t]{3}{*}{$\mathrm{UPCR}(\mathrm{g} / \mathrm{gCr})^{\mathrm{b}}$} & $<0.55$ & 146 & $(56.59)$ & 29 & $(19.86)$ & Reference \\
\hline & $\geq 0.55$ & 19 & $(7.36)$ & 10 & $(52.63)$ & $4.483(1.669-12.041)$ \\
\hline & Unknown $^{\mathrm{a}}$ & 93 & $(36.05)$ & 25 & $(26.88)$ & \\
\hline \multirow{2}{*}{$\begin{array}{l}\text { Specific concomitant } \\
\text { medication }^{c}\end{array}$} & No & 52 & $(20.16)$ & 12 & $(23.08)$ & Reference \\
\hline & Yes & 206 & $(79.84)$ & 52 & $(25.24)$ & $1.126(0.549-2.307)$ \\
\hline \multirow[t]{2}{*}{ Concomitant antimetabolites } & No & 23 & $(8.91)$ & 7 & $(30.43)$ & Reference \\
\hline & Yes & 235 & (91.09) & 57 & $(24.26)$ & $0.732(0.287-1.868)$ \\
\hline \multirow{2}{*}{$\begin{array}{l}\text { Concomitant } \\
\text { immunosuppressants }\end{array}$} & No & 1 & $(0.39)$ & 0 & $(0.00)$ & Reference \\
\hline & Yes & 257 & $(99.61)$ & 64 & $(24.90)$ & - \\
\hline \multirow[t]{3}{*}{ CNI dose reduction $^{\mathrm{d}}$} & No & 152 & $(58.91)$ & 37 & $(24.34)$ & Reference \\
\hline & Yes & 100 & $(38.76)$ & 25 & $(25.00)$ & $1.036(0.577-1.860)$ \\
\hline & Unknown $^{\mathrm{a}}$ & 6 & $(2.33)$ & 2 & $(33.33)$ & \\
\hline
\end{tabular}

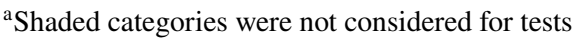

${ }^{\mathrm{b}}$ At the start of EVR treatment

${ }^{\mathrm{c}}$ Angiotensin II receptor antagonists, angiotensin-converting enzyme inhibitors, treatment drugs for dyslipidemia, and treatment drugs for diabetes mellitus including insulin

${ }^{\mathrm{d}}$ Patients with CNI dose reduction were defined as those in whom the dosage of CNIs was reduced by $\geq 30 \%$ relative to the dose at the start of treatment at $\geq 2$ time points out of all assessment points

$A E$ adverse event, $C I$ confidence interval, $C N I$ calcineurin inhibitor, $e G F R$ estimated glomerular filtration rate, $E V R$ everolimus, $H L A$ human 
Table 5 (continued)

leukocyte antigen, $M D R D$ modification of diet in renal disease, $M M F$ mycophenolate mofetil, $O R$ odds ratio, $T x$ transplantation, $U P C R$ urinary protein/creatinine ratio

nephrosclerosis.

Randomized studies with early EVR initiation ( $<6$ months post-transplant) have shown clinical benefits of using EVR. In the ZEUS study, conversion to EVR with cyclosporine elimination showed significant improvement in renal function up to 5 years $(P<0.001)$, while maintaining efficacy and safety $[17,18]$. Similarly, conversion to EVR with cyclosporine elimination was associated with a significant increase in mGFR $(P=0.012)$ at M12 in the CENTRAL study [19] and a significant increase in eGFR $(P<0.001)$ up to M24 in the ELEVATE study [20]. Results from the largest study in de novo KTx patients (TRANSFORM) with $50 \%$ living donor transplants showed comparable antirejection efficacy, stable renal function, and low incidence of de novo donor-specific antibodies (dnDSA) and viral infections with EVR-based regimen at M24 [9]. The clinical benefit of EVR was also evident in de novo Japanese KTx patients in the 12-month A1202 study, where $\mathrm{EVR}+$ reduced-exposure cyclosporine $(\mathrm{EVR}+\mathrm{rCsA})$ group showed numerically higher median eGFR values $(58 \mathrm{~mL} /$ $\min / 1.73 \mathrm{~m}^{2}$ versus $55.25 \mathrm{~mL} / \mathrm{min} / 1.73 \mathrm{~m}^{2} ; P=0.063$ ) and comparable safety versus $\mathrm{MMF}+$ standard-exposure cyclosporine (MMF + sCsA) group. The graft survival rate at M12 was $100 \%$ in both the treatment groups [21]. Moreover, when participants $(N=24)$ from this study were followed-up at 10 years, the graft survival rate was maintained in the EVR $+\mathrm{rCsA}(100 \%)$ group but was reduced in the $\mathrm{MMF}+\mathrm{sCsA}(90.9 \%)$ group. In addition, dnDSA-free survival was significantly better in the EVR + rCsA group [22]. Although these results are from a small population, early EVR initiation showed better clinical outcomes. More robust clinical evidence is needed to conclude the long-term benefits of EVR in Japanese KTx patients.

The main limitations of this survey were lack of a comparator arm to conclude the clinical benefits of EVR and a limited follow-up period of 2 years. In addition, protocol-defined criteria for confirmation of rejection and graft survival were not applicable. However, the survey provided useful insights into the safety and effectiveness of EVR use in Japanese KTx patients in a real-world setting.

In conclusion, this survey showed that EVR initiation can facilitate the reduction of mean daily doses of tacrolimus and cyclosporine to $\sim 79$ and $\sim 64 \%$ by 2 years, respectively. Although overall patient and graft survival rates at 2 years were high, graft survival rates were affected by baseline eGFR and UPCR values. Renal impairment was higher in patients with poor baseline eGFR and UPCR. Thus, early EVR initiation ( $<6$ months post-transplant) may be considered in maintenance KTx patients to prevent renal function deterioration. No new safety concerns for EVR use in Japanese maintenance KTx patients were identified during the survey.

Supplementary Information The online version contains supplementary material available at https://doi.org/10.1007/s10157-021-02024-9.

Acknowledgements The authors thank the patients and the investigators who participated in this survey, as well as Peter Bernhardt (Novartis Pharma AG) and Osamu Kamisawa (former employee, Novartis Pharma K.K.) for their contributions to the study design. The authors thank Ryosuke Imada and Asako Itakura (Novartis Pharma K.K.) as well as Moksha Shah and Aparajita Mandal (Novartis Healthcare Pvt. Ltd.) for medical writing and editorial assistance.

Author contributions NH: Designed research/study and wrote the paper. MY: Performed research/study. SK: Analyzed data. YW: Interpretation of data for the study.

Funding The study was funded by Novartis Pharma K.K., Japan.

\section{Compliance with ethical standards}

Conflict of interest Employment: Naomi Hayase, Mariko Yamada, Shuhei Kaneko, and Yoko Watanabe (Novartis Pharma K.K.).

Ethical approval In accordance with good post-marketing study practice (GPSP), the requirement of ethical approval by an institutional review board was not mandatory for this post-marketing surveillance study.

Informed consent Written informed consent was obtained from all patients before enrollment.

Open Access This article is licensed under a Creative Commons Attribution 4.0 International License, which permits use, sharing, adaptation, distribution and reproduction in any medium or format, as long as you give appropriate credit to the original author(s) and the source, provide a link to the Creative Commons licence, and indicate if changes were made. The images or other third party material in this article are included in the article's Creative Commons licence, unless indicated otherwise in a credit line to the material. If material is not included in the article's Creative Commons licence and your intended use is not permitted by statutory regulation or exceeds the permitted use, you will need to obtain permission directly from the copyright holder. To view a copy of this licence, visit http://creativecommons.org/licenses/by/4.0/.

\section{References}

1. Chapman JR. Chronic calcineurin inhibitor nephrotoxicity-lest we forget. Am J Transplant. 2011;11(4):693-7.

2. Nankivell BJ, Borrows RJ, Fung CL, O'Connell PJ, Chapman JR, Allen RD. Calcineurin inhibitor nephrotoxicity: longitudinal assessment by protocol histology. Transplantation. 2004;78(4):557-65. 
3. Liptak P, Ivanyi B. Primer: histopathology of calcineurininhibitor toxicity in renal allografts. Nat Clin Pract Nephrol. 2006;2(7):398-404.

4. Kasiske BL, Snyder JJ, Gilbertson D, Matas AJ. Diabetes mellitus after kidney transplantation in the United States. Am J Transplant. 2003;3(2):178-85.

5. Burroughs TE, Swindle J, Takemoto S, Lentine KL, Machnicki G, Irish WD, et al. Diabetic complications associated with new-onset diabetes mellitus in renal transplant recipients. Transplantation. 2007;83(8):1027-34.

6. Ojo AO. Cardiovascular complications after renal transplantation and their prevention. Transplantation. 2006;82(5):603-11.

7. Jouve T, Noble J, Rostaing L, Malvezzi P. Tailoring tacrolimus therapy in kidney transplantation. Expert Rev Clin Pharmacol. 2018;11(6):581-8.

8. Witzke O, Sommerer C, Arns W. Everolimus immunosuppression in kidney transplantation: What is the optimal strategy? Transplant Rev (Orlando). 2016;30(1):3-12.

9. Berger SP, Sommerer C, Witzke O, Tedesco H, Chadban S, Mulgaonkar S, et al. Two-year outcomes in de novo renal transplant recipients receiving everolimus-facilitated calcineurin inhibitor reduction regimen from the TRANSFORM study. Am J Transplant. 2019;19(11):3018-34.

10. Uchida J, Iwai T, Nakatani T. Introduction of everolimus in kidney transplant recipients at a late posttransplant stage. World J Transplant. 2018;8(5):150-5.

11. Sánchez-Fructuoso AI, Ruiz JC, Calvo N, Rodrigo E, Perez-Flores I, Gómez-Alamillo C, et al. Everolimus as primary immunosuppression in kidney transplantation: experience in conversion from calcineurin inhibitors. Transplantation. 2012;93(4):398-405.

12. Holdaas H, Rostaing L, Serón D, Cole E, Chapman J, Fellstrøm B, et al. Conversion of long-term kidney transplant recipients from calcineurin inhibitor therapy to everolimus: a randomized, multicenter, 24-month study. Transplantation. 2011;92(4):410-8.

13. Nanmoku K, Kurosawa A, Kubo T, Shinzato T, Shimizu T, Kimura $\mathrm{T}$, et al. Effective and safe reduction of conventional immunosuppressants using everolimus in maintenance kidney transplant recipients. Transplant Proc. 2017;49(8):1724-8.

14. Kamisawa O, Irokawa $T$, Yamada M. Results of post-marketing surveillance for Japanese kidney transplant patients using everolimus $\left(\right.$ Certican $\left.{ }^{\circledR}\right)$. Organ Biology. 2018;25(1):41-50.
15. Matsuo S, Imai E, Horio M, Yasuda Y, Tomita K, Nitta K, et al. Revised equations for estimated GFR from serum creatinine in Japan. Am J Kidney Dis. 2009;53(6):982-92.

16. Nojima M, Yamada Y, Higuchi Y, Shimatani K, Kanematsu A, Yamamoto S. Immunosuppression modification by everolimus with minimization of calcineurin inhibitors recovers kidney graft function even in patients with very late conversion and also with poor graft function. Transplant Proc. 2017;49(1):41-4.

17. Budde K, Becker T, Arns W, Sommerer C, Reinke P, Eisenberger $\mathrm{U}$, et al. Everolimus-based, calcineurin-inhibitor-free regimen in recipients of de-novo kidney transplants: an open-label, randomised, controlled trial. Lancet. 2011;377(9768):837-47.

18. Budde K, Lehner F, Sommerer C, Reinke P, Arns W, Eisenberger $\mathrm{U}$, et al. Five-year outcomes in kidney transplant patients converted from cyclosporine to everolimus: the randomized ZEUS study. Am J Transplant. 2015;15(1):119-28.

19. Mjörnstedt L, Sørensen SS, von Zur MB, Jespersen B, Hansen JM, Bistrup C, et al. Improved renal function after early conversion from a calcineurin inhibitor to everolimus: a randomized trial in kidney transplantation. Am J Transplant. 2012;12(10):2744-53.

20. de Fijter JW, Holdaas H, Øyen O, Sanders JS, Sundar S, Bemelman FJ, et al. Early conversion from calcineurin inhibitor- to everolimus-based therapy following kidney transplantation: results of the randomized ELEVATE trial. Am J Transplant. 2017;17(7):1853-67.

21. Takahashi K, Uchida K, Yoshimura N, Takahara S, Teraoka S, Teshima R, et al. Efficacy and safety of concentration-controlled everolimus with reduced-dose cyclosporine in Japanese de novo renal transplant patients: 12 -month results. Transplant Res. 2013;2(1):14.

22. Narumi S, Watarai Y, Goto N, Hiramitsu T, Tsujita M, Okada M, et al. Everolimus-based immunosuppression possibly suppresses mean fluorescence intensity values of de novo donor-specific antibodies after primary kidney transplantation. Transplant Proc. 2019;51(5):1378-81.

Publisher's Note Springer Nature remains neutral with regard to jurisdictional claims in published maps and institutional affiliations. 